\title{
STRUCTURAL COMPOSITION OF PROTOZOOPLANKTON COMMUNITIES IN RELATION TO ENVIRONMENTAL FACTORS IN SHALLOW LAKES AND RESERVOIRS OF RİGA, LATVIA
}

\author{
Linda Buholce $^{1 \#}$, Vita Līcīte ${ }^{2}$, Elmīra Boikova ${ }^{2}$, and Uldis Botva ${ }^{2}$ \\ ${ }^{1}$ University of Latvia, Kronvalda bulv. 4, Rīga, LATVIA; \\ lindabuholce@gmail.com \\ ${ }^{2}$ Institute of Biology, University of Latvia, Miera iela 3, Salaspils, LATVIA; \\ vita@ezeri.Iv, elmira@hydro.edu.Iv \\ \# Corresponding author
}

Communicated by Gunta Sprinǵge

\begin{abstract}
Protozooplankton are dominant grazers of phytoplankton and an important component of the microbial food web, as a link between pico and nanoplankton to higher trophic levels. Their fast growing rate, relative abundance, biomass and diversity are used as indicators of organic and toxic pollution. The impact of urbanisation on ecosystems and their sustainability and biodiversity have recently been much studied. We studied the protozooplankton ciliate communities during the vegetation period from April to October in two small lakes (Bābelitis, Gailezers) and two reservoirs (Bolderāja, Saurieši). The largest peak of biomass $\left(15.7 \times 10^{2} \mathrm{mg} / \mathrm{l}\right)$ was found in Gailezers Lake in August and of abundance $\left(60.2 \times 10^{3} \mathrm{org} / \mathrm{l}\right)$ in Bābelitis Lake in July. The lowest biomass $(0.006 \mathrm{mg} / \mathrm{l})$ and abundance $\left(0.12 \times 10^{3} \mathrm{org} / \mathrm{l}\right)$ were found in the Saurieši Reservoir station. The most abundant ciliates were from the order Oligotrichida.
\end{abstract}

Key words: urban ecology, ciliated protozoa, plankton, shallow lake, structural composition.

\section{INTRODUCTION}

The $21^{\text {st }}$ century will be the century of urbanisation (Marcel and Wilfried, 2014). Urban areas rely on ecosystems beyond the city limits, and also benefit from internal urban ecosystems (Bolund and Hunhammar, 1999). In the 1920s, a small group of University of Chicago sociologists developed the term "urban ecology", which became part of human ecology (Wu, 2014). Urban ecosystems are fragmented landscapes dominated by buildings, roadways and pollution-tolerant vegetation (Nasell-Flores, 2008). The study of urban areas is important due to the altered urban environment itself and its impacts on ecosystem services for the fast increasing urban population (Lakes and Kim, 2012). Urban freshwater ecosystems are among the most threatened ecosystems in the world (Anonymous, 2005; Yoshioka et al., 2014). Shallow lakes and reservoirs are mostly ignored in most studies of global processes (Downing, 2010), while some have been carried out (Pfister $e t$ al., 2002; Auer et al., 2004; Naselli-Flores, 2008; Downing, 2010 etc.; Zou et al., 2013). Urban lakes tend to have a higher trophic state than in non-urban lakes (Naselli-Flores, 2008). In the mentioned previous studies, one of the best water quality indicators had been suggested to be ciliated protozoans.
Protozooplankton is the dominant grazer of phytoplankton and is an important component of the microbial food web as a link between pico and nanoplankton to higher trophic levels (Fenchel, 1987; Laybourn-Parry, 1992; Zou et al., 2013). Their fast growing rate, high abundance, biomass and diversity are used as indicators of organic and toxic pollution (Foissner, 1988; Pfister et al., 2002). There is some evidence that ciliated protozoans can promote the availability of phosphorus and nitrogen for phytoplankton growth (Xu and Cronberg, 2010). The significance of small-sized $(<40 \mu \mathrm{m})$ individuals tends to increase with trophy (Beaver and Crisman, 1982; Van Wichelena et al., 2013), while large-sized ciliates are characteristic of oligotrophic ecosystems (Velho et al., 2005).

This study was carried out to provide new information on water quality of Rīga city lakes and reservoirs. There was a need to provide new information about planktonic ciliate communities in shallow lakes and reservoirs, as there were only a few studies, including a doctoral thesis (Liepa, 1975), on benthic ciliate ecology in Latvian freshwater rivers. Large studies on ciliate ecology and ecotoxicology have been carried out by E. Boikova in the Gulf of Riga and open Baltic Sea (Boikova, 1989). 


\section{MATERIALS AND METHODS}

Sampling sites. Selection of sample locations (Table 1) was based on different levels of anthropogenic pressure on waterbodies. The sampling sites were located two small lakes (Bābelītis, Gaiḷezers) and two reservoirs (Bolderāja, Saurieši) in Rīga (Fig. 1). The bottom of Bābelītis Lake was sludge, despite sandy coasts. Dominant macrophytes were Sparganium, Carex, Scirpus and Nuphar. Gailezers Lake is a typical macrophyte lake overgrown with Phragmites and Scirpus. The largest area of Gailezers Lake was covered by Nymphaea species. The lakebed was sludgy and slope of the shore was low. The shores of Bolderāja Reservoir were overgrown with Salix and Hippopha and the dominant macrophyte was Phragmites. A pine forest occurred beside the Bolderāja Reservoir. The bottom of the reservoir was mostly sandy, in some places sludgy. The bottom of Saurieši Reservoir was gypsum deposits. Typha and Phragmites occurred along the shores of Saurieši Reservoir. Dead tree appear at low water levels.

Sampling. Water samples were taken monthly during the vegetation period from April to October 2014 in the two lakes and two reservoirs. Each sample consisted of $250 \mathrm{ml}$ lake water taken from the surface. The water samples were fixed with Lugol's solution (2\% final concentration) and stored at $4{ }^{\circ} \mathrm{C}$. Measured environmental variables were temperature, oxygen, nutrients $\mathrm{NO}_{2}-\mathrm{N}, \mathrm{NO}_{3}-\mathrm{N}, \mathrm{NH}_{4}-\mathrm{N}$, $\mathrm{PO}_{4}-\mathrm{P}$, tot $\mathrm{P}$, tot $\mathrm{N}$ and Chlorophyll a.

Quantitative and qualitative analysis of ciliates. Ciliates were counted in sedimentation chambers (10 and $25 \mathrm{ml}$ ) using an inverted microscope Leica at 200-fold magnification following the Utermöhl method (Paxinos and Mitchell, 2000). Sedimentation time was more than 24 h. Some ciliates were identified only to genus level, but all specimens in

Table 1

COORDINATES OF SAMPLE LOCATIONS

\begin{tabular}{|c|c|c|c|c|}
\hline & $\begin{array}{c}\text { Bābelītis } \\
\text { Lake }\end{array}$ & $\begin{array}{c}\text { Gailezers } \\
\text { Lake }\end{array}$ & $\begin{array}{l}\text { Bolderāja } \\
\text { Reservoir }\end{array}$ & $\begin{array}{l}\text { Saurieši } \\
\text { Reservoir }\end{array}$ \\
\hline Latitude & $\mathrm{N} 56^{\circ} 99.21^{\prime}$ & N56 $97.00^{\prime}$ & $\mathrm{N} 57^{\circ} 01.85^{\prime}$ & $\mathrm{N} 56^{\circ} 91.43^{\prime}$ \\
\hline Longitude & $\mathrm{E} 24^{\circ} 22.09^{\prime}$ & $\mathrm{E} 24^{\circ} 23.61^{\prime}$ & $\mathrm{E} 24^{\circ} 03.61^{\prime}$ & $\mathrm{E} 24^{\circ} 34.93^{\prime}$ \\
\hline
\end{tabular}

samples were measured. Identification was made using literature using Kahl (1930-1935) and Corliss (2007).

Biomass and biodiversity index of ciliated protozoans. Biomass was estimated using simple geometric shapes (e.g. sphere, ellipsoid, cone with the hemisphere) using the formulas given by Hillebrand et al. (1999) as follows,

For ellipsoids $-\left(\frac{2.14}{6}\right) \cdot d^{2} \cdot h$

For sphere $-\left(\frac{2.14}{6}\right) \cdot d^{3}$

For cones with the hemisphere $\left(\frac{2.14}{12}\right) \cdot d^{2} \cdot\left(h+\frac{d}{2}\right)$

in which $d$ is diameter $(\mu \mathrm{m}) ; h$ is height $(\mu \mathrm{m})$.

The Shannon-Wiener biodiversity index of the ciliate communities was calculated using the formula given by Shannon and Weaver (1949) and Keylock (2005) as follows,

$(H)=-\sum_{i=1}^{s} p_{i} \ln p_{i}$

in which $p$ is the proportion $(\mathrm{n} / \mathrm{N})$ of individuals of a particular species (n) divided by the total number of individuals $(\mathrm{N})$, and $s$ is the number of species.

Principal components analysis (PCA) was used to summarize ecosystem relations with environmental variables and ciliate species number during the investigation period concentrate.

\section{RESULTS}

Ciliated protozoan composition. During the investigation period (from April to October 2014), 9 genera and 4 species from 7 orders were found. Among them, 6 taxons were from Oligotrichida, 2 taxons from Peritrichia, and but 1 from Choreotrichida, Gymnostomatida, Hymenostomata, Cyclotrichida and Prostomatida (Table 2). Common genera were Strobilidium, Strombidium, Lohmaniella, Cyclidium, Halteria, and Vorticella.

Seasonal change of ciliate abundance and biomass. Seasonal dynamics of mean ciliate abundance had one peak

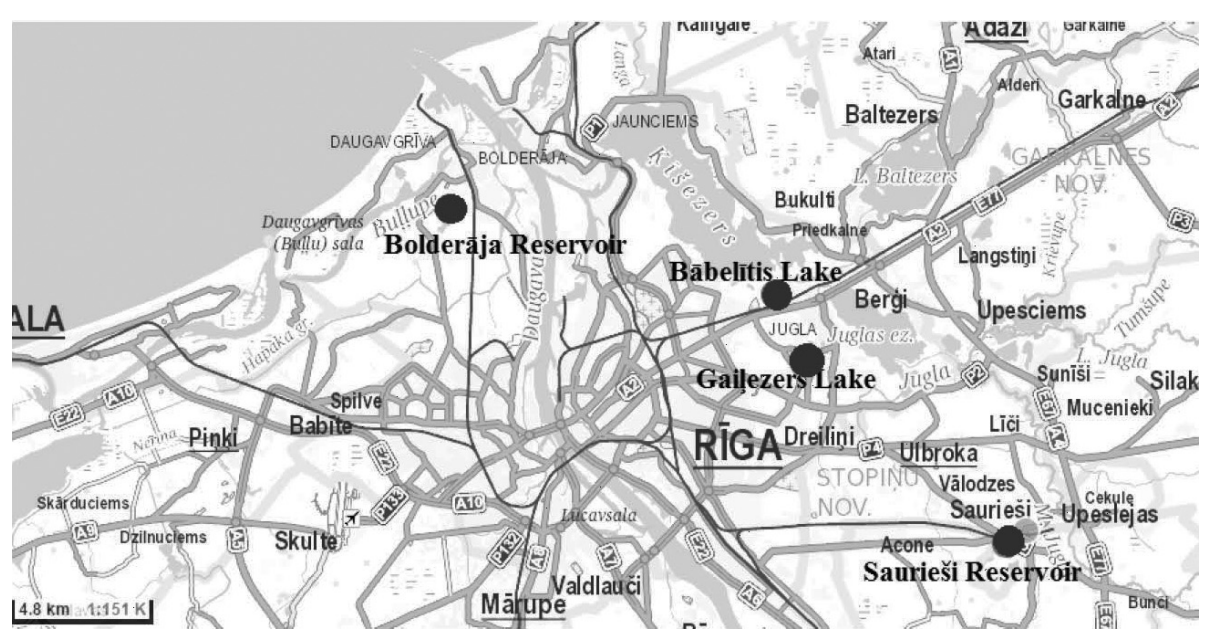


SPECIES LIST OF CILIATE TAXONS FOUND IN RIGA CITY SHALLOW LAKES AND RESERVOIRS DURING THE INVESTIGATION PERIOD (April till October 2014)

\begin{tabular}{|c|c|c|c|c|}
\hline Taxon (org/l) & $\begin{array}{l}\text { Bolderāja } \\
\text { Reservoir }\end{array}$ & \begin{tabular}{|l|} 
Sauriešu \\
Reservoir
\end{tabular} & $\begin{array}{c}\text { Bābelītis } \\
\text { Lake }\end{array}$ & $\begin{array}{c}\text { Gailezers } \\
\text { Lake }\end{array}$ \\
\hline \multicolumn{5}{|l|}{ Prostomatida } \\
\hline Coleps hirtus & - & - & 8 & - \\
\hline \multicolumn{5}{|l|}{ Peritrichia } \\
\hline Vorticella sp. & - & 4 & 215 & 12 \\
\hline Epistilis sp. & 44 & - & - & - \\
\hline \multicolumn{5}{|l|}{ Hymenostomata } \\
\hline Cyclidium sp. & 96 & 3 & 118 & 44 \\
\hline \multicolumn{5}{|l|}{ Cyclotrichida } \\
\hline Mesodinium pulex & - & 12 & - & - \\
\hline \multicolumn{5}{|l|}{ Gymnostomatida } \\
\hline Dileptus sp. & - & - & 8 & - \\
\hline \multicolumn{5}{|l|}{ Oligotrichida } \\
\hline Halteria sp. & 29 & 6 & 92 & 106 \\
\hline Strobilidium sp. & 131 & 73 & 2922 & 139 \\
\hline Strombidium conicum & 16 & 84 & 88 & 4 \\
\hline Strombidium sp. & 251 & 53 & 1058 & 168 \\
\hline Tintinnidae sp. & - & - & 8 & 6 \\
\hline Tintinnopsis codonella & - & - & 28 & - \\
\hline \multicolumn{5}{|l|}{ Choreotrichida } \\
\hline Lohmaniella sp. & 57 & 6 & 102 & 28 \\
\hline Ciliata & 119 & 15 & 39 & 4 \\
\hline
\end{tabular}

(Fig. 2) $\left(23 \times 10^{3} \mathrm{org} / \mathrm{l}\right)$, which occurred in July, and the lowest ciliate density $\left(5.8 \times 10^{3} \mathrm{org} / \mathrm{l}\right)$ was observed in April. The highest peak of mean ciliate biomass occurred in August $\left(6.2 \times 10^{2} \mathrm{org} / \mathrm{l}\right)$, and the lowest peak in October $\left(1.6 \times 10^{2} \mathrm{org} / \mathrm{l}\right)$. Seasonal dynamics of total abundance of ciliates is shown in Fig. 3. The greatest peak of biomass $\left(15.7 \times 10^{2} \mathrm{mg} / \mathrm{l}\right)$ occurred in Gailezers Lake in August and abundance $\left(60.2 \times 10^{3} \mathrm{org} / \mathrm{l}\right)$ in Bābelitis Lake in July. The lowest biomass $(0.006 \mathrm{mg} / \mathrm{l})$ and abundance $\left(0.12 \times 10^{3}\right.$ org/l) were observed in the Saurieši reservoir station. Lakes (Bābelītis and Gail̨ezers) had larger biomass and abundance than reservoirs (Bolderāja and Saurieši). Seasonal changes of proportional abundance of major ciliated protozoan groups are demonstrated in Fig. 4. Oligotrichida (Halteria sp., Strombidium sp., Strobilidium sp., Tintinopsis sp.) dominated in urban hydroecosystems (more than 75\%). Hymenostomata (Ciclydium sp.) and Peritrichia (Vorticella sp.) mostly were found in lakes, and undefined ciliata species mostly in reservoirs.

Size structure of ciliated protozoans assemblages. Smallsized $(\leq 30 \mu \mathrm{m})$ ciliates dominated in spring, and mediumsized (30-55 $\mu \mathrm{m})$ ciliates in summer and autumn (Fig. 5). Medium-sized ciliates dominated in all stations during the investigation period. One-third of ciliates were small- sized $(\leq 30 \mu \mathrm{m})$. Large-sized $(\geq 55 \mu \mathrm{m})$ ciliates dominated in spring in Bolderāja Reservoir, and small-sized $(\leq 30 \mu \mathrm{m})$ ciliates in summer and autumn seasons in Saurieši Reservoir.

Seasonal changes of species richness and biodiversity index. The highest taxon richness (9) and biodiversity index (1.4) peaks were found in Bābelītis Lake in August. The lowest Shannon-Wiener biodiversity index was in Bābelītis Lake in June (0.2) and the lowest taxon richness (2) in Saurieši Reservoir in May and June (Fig. 6). The highest taxon richness was generally higher in lakes (5.1) than reservoirs (4.2). The highest average taxon richness (5.6) and Shannon-Wiener biodiversity index (1.0) was in Bābelītis Lake. The lowest mean taxon richness (3.9) and ShannonWiener biodiversity index (0.8) was in Saurieši Reservoir.
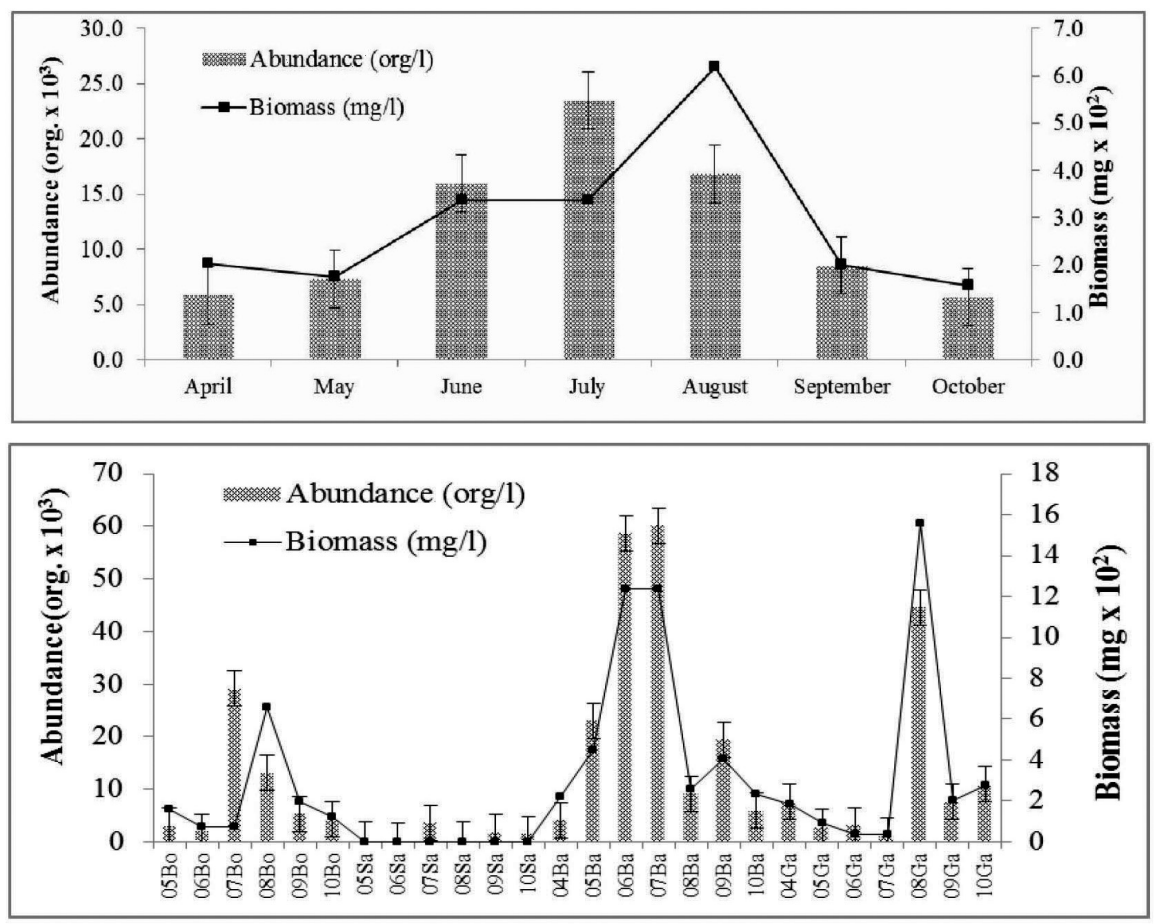

Fig. 2. Seasonal changes of average ciliate abundance and biomass during the investigation period (from April till October). 


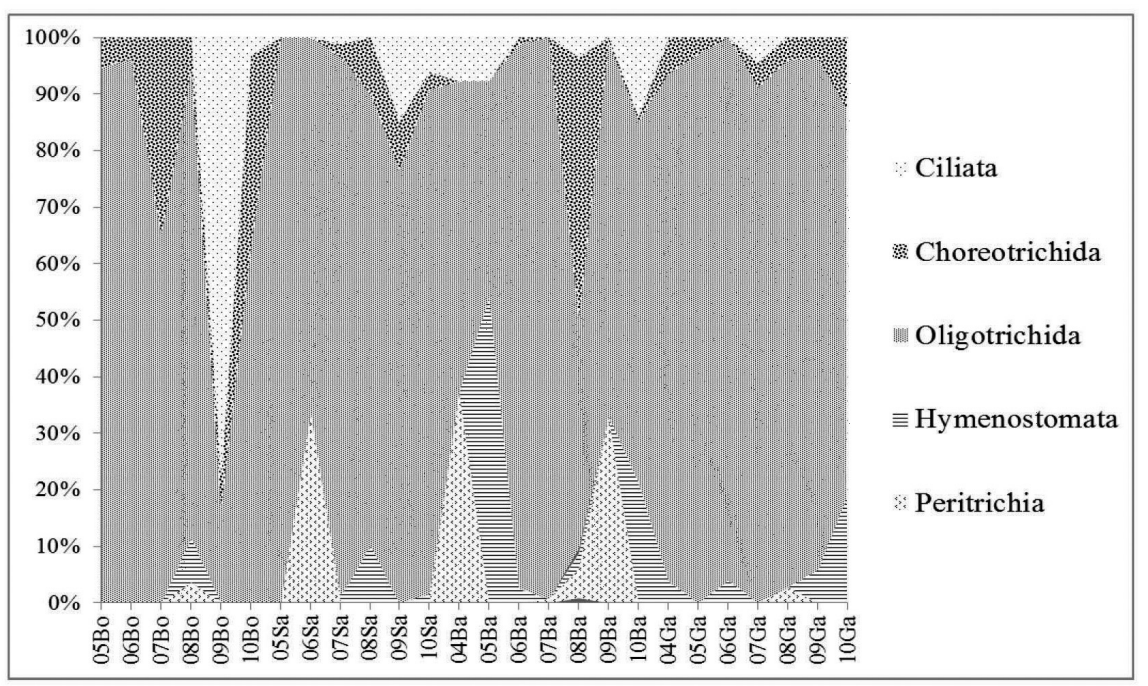

Fig. 4. Seasonal changes of proportional abundance of major ciliated protozoan groups in Rīga city lakes (Bābelītis, Gaiḷezers), reservoirs (Bolderāja, Saurieši). For abbreviations see Fig. 3.

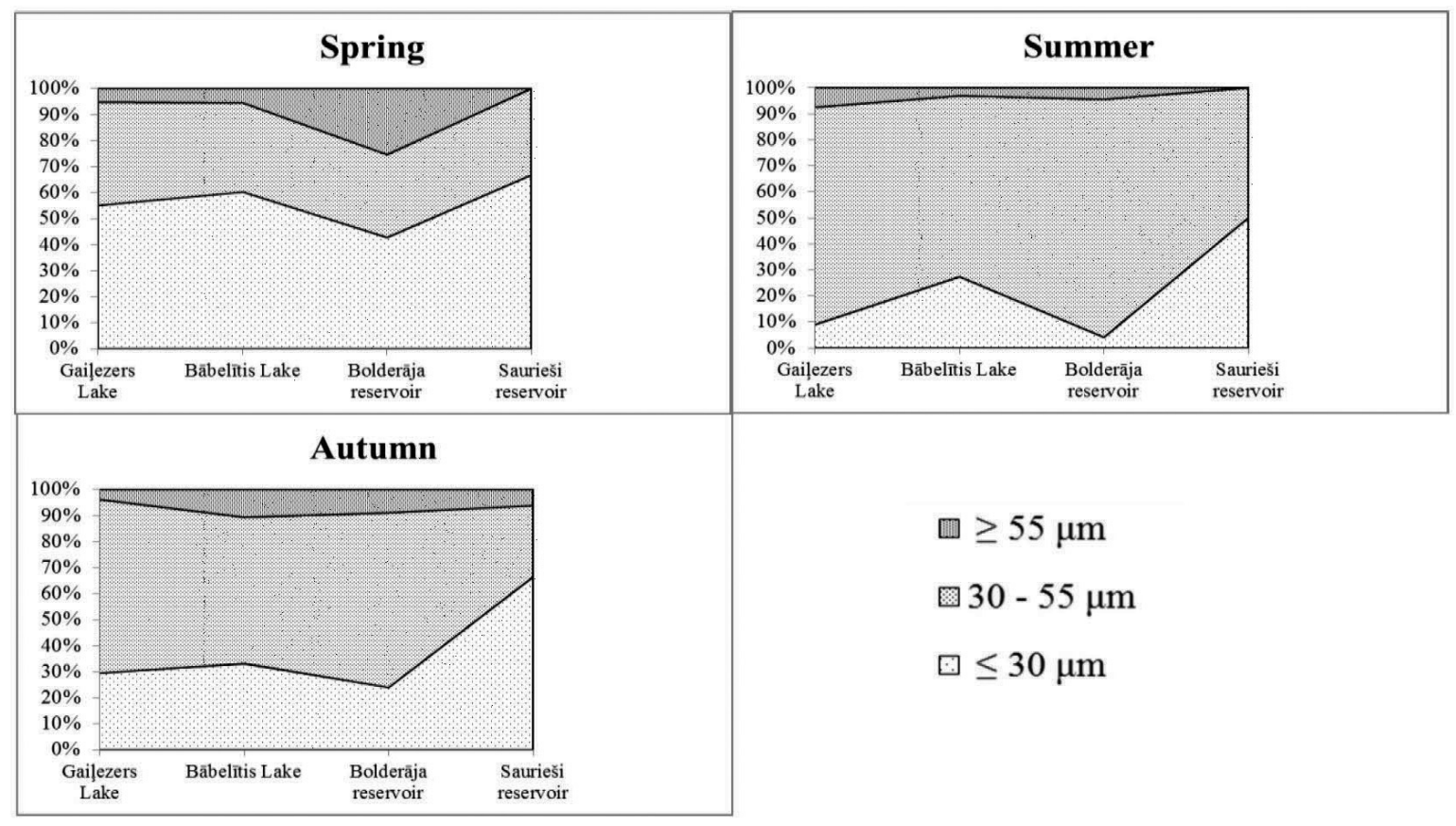

Fig. 5. Size structure of average ciliate assemblages during the investigation period in Rìga city shallow lakes and reservoirs.

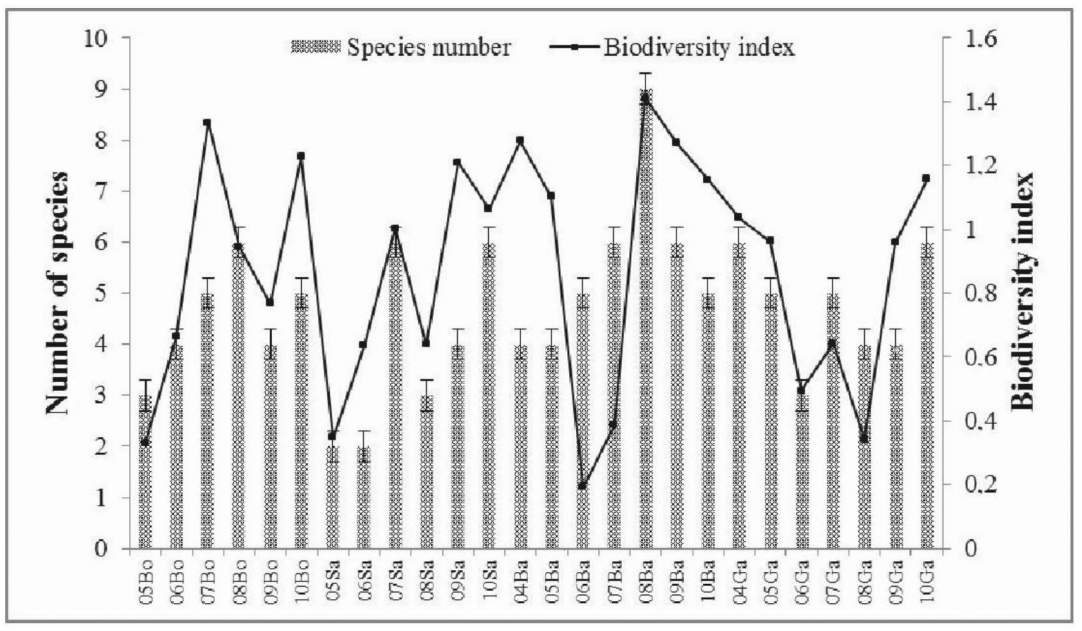

Fig. 6. Seasonal changes of ciliate richness and biodiversity index during the investigation period in Rīga city shallow lakes and reservoirs. For abbreviations see Fig. 3.

Seasonal changes of environmental variables. Figure 7 shows seasonal dynamics of temperature, Nmin, dissolved oxygen and PO4. The highest water temperature occurred in
August in Bābelitis Lake $\left(26.0^{\circ} \mathrm{C}\right)$, and the lowest in April in Bābelītis Lake $\left(7.6^{\circ} \mathrm{C}\right)$. Nmin was higher in Saurieši reservoir $(28.2 \mu \mathrm{mol}-\mathrm{N} / \mathrm{l})$. The lowest dissolved oxygen values 
occurred in September in Gailezers Lake $(3.4 \mathrm{mg} / \mathrm{l})$, and the highest in May in Bolderājas Reservoir (8.7 mg/l). The highest PO4 concentration $(0.24 \mu \mathrm{mol} / \mathrm{l})$ occurred in October in Bābelìtis Lake.

Ciliate abundance, biomass and size structure relations with environmental variables. Ecosystem relations with environmental variables and ciliate species number during the investigation period concentrate in Bābelītis Lake, Gaiḷezers Lake and Bolderāja Reservoir shown in Fig. 8. Bray-Curtis similarity index (hierarchial clustering) of environmental variables and ciliate species number, average biomass and abundance during the investigation period show similarity between Gaiḷezers Lake and Bolderāja Reservoir, as well as Bābelītis Lake (Fig. 9). Spearman's rank correlation analysis showed that ciliate abundance, biomass and size structure were generally correlated with biotic and abiotic factors $(p \leq 0.05)$.
Gailezers Lake. Average ciliate abundance and biomass were significantly correlated positively with Chlorophyll a, and Nmin negatively with ciliate abundance and biomass. $\mathrm{pH}$ was correlated negatively and $\mathrm{NH} 4$ positively with abundance of small-sized $(\leq 30 \mu \mathrm{m})$ ciliates. Abundance of ciliates with size $\leq 30 \mu \mathrm{m}$ and $\geq 55 \mu \mathrm{m}$ were correlated negatively with dissolved oxygen. Average abundance of largesized $(\geq 55 \mu \mathrm{m})$ ciliated protozoans were correlated negatively with $\mathrm{pH}$ and $\mathrm{Nmin}$.

Saurieši Reservoir. Ciliate abundance correlated positively with $\mathrm{pH}$, and correlated negatively with total phosphorous. Biomass of ciliates with size $\leq 30 \mu \mathrm{m}$ and $\geq 55 \mu \mathrm{m}$ were correlated negatively with $\mathrm{PO}_{4}$ and dissolved oxygen.

Bolderāja Reservoir. Average ciliate abundance, biomass and abundance of large-bodied ciliates were correlated negatively with nitrogen. Abundance of small-sized ciliates was correlated positively with Chlorophyll a. Abundance of
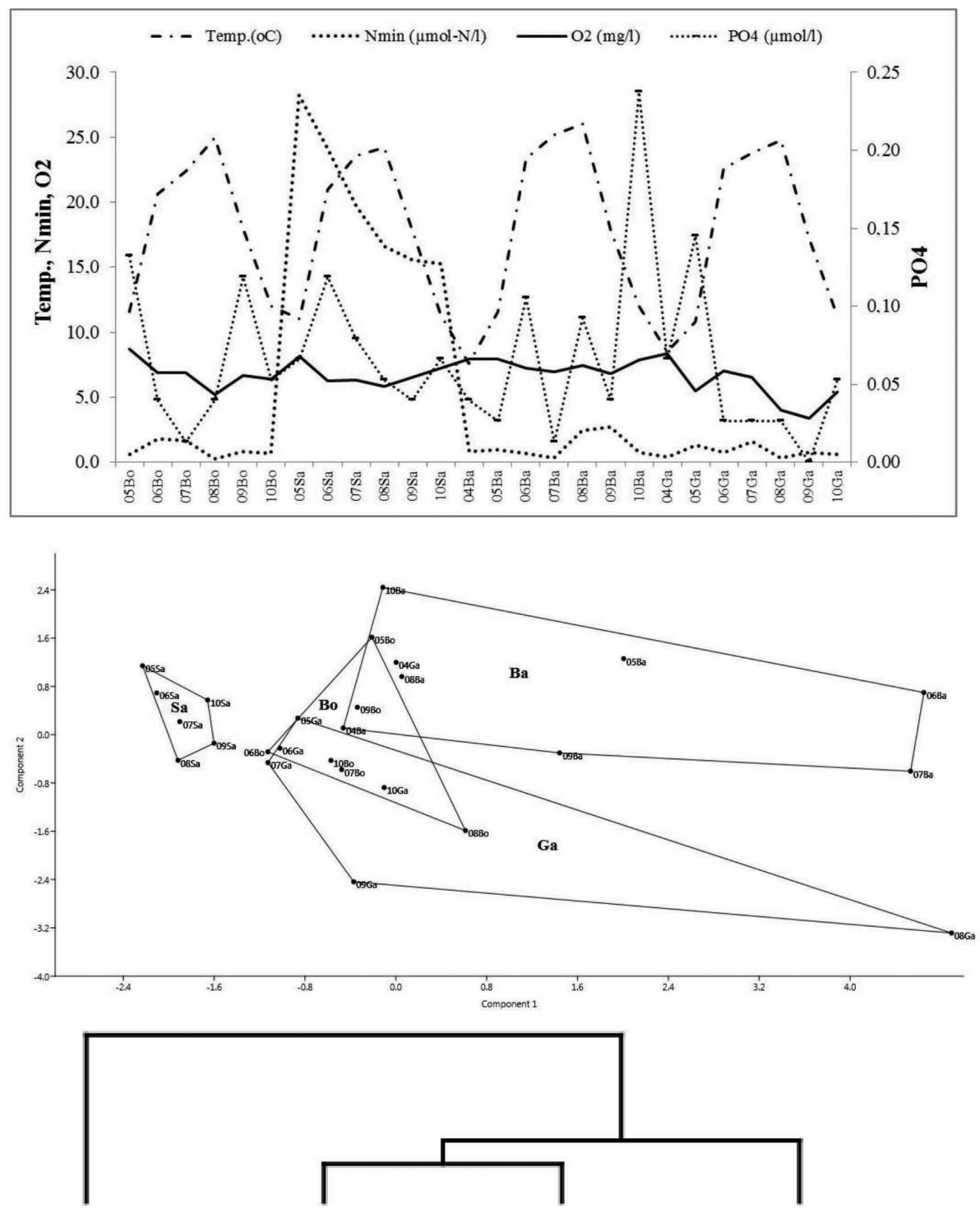
Saurieši
Bolderāja
Gailezers
Lake
Bābelītis
Lake

Fig. 7. Environmental variable (temp., Nmin., $\mathrm{O}_{2}$, $\mathrm{PO}_{4}$ ) dynamics during the investigation period in shallow lakes and reservoirs of Rīga. For abbreviations see Fig. 3.
Fig. 8. Principal components analysis (PCA), correlation matrix between-groups of ecosystem relations with environmental variables and ciliate species number during the investigation period in Riga city shallow lakes and reservoirs. For abbreviations see Fig. 3.
Fig. 9. Hierarchial clustering, paired group (UPGMA) algorithm, Bray-Curtis similarity index of environmental variables and ciliate species number, average biomass and abundance during the investigation period in Rīga city shallow lakes and reservoirs. 
ciliates with size $30-55 \mu \mathrm{m}$ were correlated negatively with dissolved oxygen.

Bābelītis Lake. There was no correlation between ciliate abundance, biomass, size structure and biotic or abiotic factors $(p \leq 0.05)$.

\section{DISCUSSION}

Ciliate communities were dominated by Oligotrichida, Peritrichia, Cyclotrichida, Choreotrichida, Gymnostomatida, Hymenostomata, and Prostomatida. All these groups have been reported as relatively common, for example, in Lake Dongshan (Zou et al., 2013), Lake Ringsjön (Xu and Cronberg, 2010), Lake Võrtsjärv (Zingel, 2001), Lake Mackenzie (Galand et al., 2008), and German lakes (Pfister et al., 2002).

Previous studies have shown that the highest peaks in ciliate abundance and biomass occur in spring (May) and in late summer (July, August) (Zingel, 2001; Xu and Cronberg, 2010; Zou et al., 2013), as also shown for Rīga city shallow lakes and reservoirs. Ciliate biomass increases with trophy level (Zou et al. 2013). High nutrient availability promotes phytoplankton and bacterial abundance, which facilitates development of planktonic ciliate populations (Velho et al., 2005). Saurieši Reservoir was characterised by a relatively low population size under conditions of typical increases of nutrient concentrations, which is in contrast to the well known trend of ciliate abundance and biomass increasing along a trophic gradient from oligotrophy to eutrophy (Zingel, 2001).

Although medium-sized $(30-55 \mu \mathrm{m})$ ciliates dominated in all stations during the investigation period, small-sized $(\leq$ $30 \mu \mathrm{m}$ ) ciliates form almost one third of size structure during the investigation period. Beaver and Crisman (1982) and Van Wichelena et al. (2013) found that large-sized ciliates $(\geq 55 \mu \mathrm{m})$ are progressively replaced by small-sized ciliates as trophic state increased. Ciliate size structure indirectly indicates different trophic roles during the growing season.

The highest number of species was found in summer and spring months, as previously observed by Zou et al. (2013). Species richness tends to increase with lake size (Van Wichelena et al. 2013). In our study, the Shannon-Wiener biodiversity index was low in spring and higher in summer, despite waterbody size.

Opinions differ on the effect of physical-chemical parameters, including concentrations of nutrients, on ciliate abundance, biomass and size structure. Considering that protozooplankton are the dominant grazers of phytoplankton, it might be expected that their optimum population growth occurs under similar conditions of UV light, high temperature, and $\mathrm{N}$ : $\mathrm{P}$ ratio $=7.2: 1$ (Horne, 1994). Relationships between ciliate abundance, biomass, size structure and biotic and abiotic factors $(p \leq 0.05)$ differed among the studied lakes and reservoirs. Results from literature also differ.
Abundance of ciliates was not significantly correlated with temperature (Stoecker et al., 1984). In bottom waters, abundance of ciliates appeared to be influenced by oxygen, temperature, and total phosphorus (Kalinowska et al., 2013). The common species were $\mathrm{pH}$-tolerant and the rare species were $\mathrm{pH}$-sensitive (Weisse and Stadler, 2006). Abundance of ciliates was positively correlated with water temperature and Chlorophyll a and negatively correlated with various inorganic nutrients, and was strongly influenced by the food availability (Yang et al., 2014). Ciliate abundance was observed to increase with Chlorophyll a concentration and total phosphorous, while temperature, $\mathrm{pH}$ and dissolved oxygen did not have any impact on ciliated organisms (Pfister et al., 2002). Ciliate dynamics need to be studied for several years to determine relationships between population variable and environmental factors in the Riga city lakes and reservoirs. Bolderāja Reservoir could be described as a similar one to a natural lake, and used as a potential reference for urban ecosystem research. For further evaluation, Gaiḷezers Lake and Bābelītis Lake can represent an urban stress level. Future research should include oligotrophic lakes to determine differences in ciliate communities.

\section{ACKNOWLEDGEMENTS}

The present work is developed owing to ESF project No. 2013 / 0060 / 1.1.1.2.0 / 13 / IDP / APIA / VIAA / 041 „, Jaunas zinātniskas grupas izveide urbānās dabas vides kvalitātes pètījumiem" (Formation of a new research group for studies of the quality of urban natural environment) (2013-2015).

\section{REFERENCES}

Anonymous (2005). Ecosystems and Human Well-being: Synthesis. Millennium Ecosystem Assessment. Island Press, Washington, DC. 64 pp.

Arndt, H., Berninger, U. (1995). Protists in aquatic food webs-complex interactions. In: Brugerolle, G., Mignot, J. P. (eds.). Protistological Actualities. Proceedings of the $2^{\text {nd }}$ European Congress of Protistology and $8^{\text {th }}$ European Conference on Ciliate Biology, Clermont-Fereand, France, 21-26 July, pp. 224-232.

Auer, B., Czioska, E., Arndt, H. (2004). The pelagic community of a gravel pit lake: Significance of Coleps hirtus viridis (Prostomatida) and its role as a scavenger. Limnologica, 34, 187-198.

Beaver, J. R., Crisman, T. L. (1982). The trophic response of ciliated protozoans in freshwater lakes. Limnol. Oceanogr., 27 (2), 246-253.

Boikova, E. (1989). Biology of the Baltic Sea Protozoans - Biomonitors of Marine Environment [Бойкова Э. Е. Простейшие - биомониторы морской среды]. Zinatne, Rīga. 215 pp. (in Russian).

Bolund, P., Hunhammar, S. (1999). Ecosystem services in urban areas. Ecol. Econ., 29 (2), 293-301.

Corliss, J. O. (2007). The Ciliated Protozoa, Characterization, Classification, and Guide to the Literature. 2nd ed. Pergamon Press, Oxford, New York. $455 \mathrm{pp}$.

Downing, J. A. (2010). Emerging global role of small lakes and ponds, little things mean a lot. Limnetica, 29 (1), 9-24.

Fenchel, T. (1987). Ecology of Protozoa. Science Technical. Madison, Wisconsin. 197 pp. 
Foissner, W. (1988). Taxonomic and nomenclatural revision of Sladecek's list of ciliates (Protozoa: Ciliophora) as indicators of water quality. Hydrobiologia, 166, 1-64.

Galand, P. E., Lovejoy, C., Pouliot J. (2008). Microbial community diversity and heterotrophic production in a coastal Arctic ecosystem. A stamukhi Lakeand its source waters. Limnol. Oceanogr., 53 (2), 813-823.

Hillebrand, H., Dürselen, C. D., Kirschtel, D., Pollingher, U., Zohary, T. (1999). Biovolume calculation for pelagic and benthic microalgae. $J$. Phycol., 35, 403-424.

Horne, A. I. (1994). Limnology. $2^{\text {nd }}$ edn. McGraw-Hill, New York. 576 pp.

Kahl, A. (1930-1935). Urtiere oder Protozoa. Jena, 886 pp.

Kalinowska, K., Guśpiel, A., Kiersztyn, B., Chróst, R. J. (2013). Factors controlling bacteria and protists in selected Mazurian eutrophic lakes (North-Eastern Poland) during spring. Aquatic Biosyst., 9 (9), 14 pp.

Keylock, C. J. (2005). Simpson diversity and the Shannon-Wiener index as special cases of a generalized entropy. Oikos, 109 (1), 203-207.

Lakes, T., Kim, H. O. (2012). The urban environmental indicator "Biotope Area Ratio". An enhanced approach to assess and manage the urban ecosystem services using high resolution remote-sensing. Ecol. Indic., 13, 93-103.

Laybourn-Parry, J. (1992). Protozoan Plankton Ecology. Chapman Hall, London. 231 pp.

Liepa, R. (1975). Structural Composition of the Ciliate Community in Relation to Wastewater Influence in Rivers of Latvia [Лиепа P. А. Изменения сообществ свободноживущих инфузорий под влиянием промышленно бытовых сточных вод в реках Латвии]. Institute of Biology, Latvian Academy of Sciences, Rīga. 171 pp. (in Russian).

Marcel, L., Wilfried, E. (eds.) (2014). Shrinking Cities, Effects on Urban Ecology and Challenges for Urban Development. $2^{\text {nd }}$ rev. edn. International Academic Publishers, Frankfurt am Main, Berlin, Bern, Bruxelles, New York, Oxford, Wien. 161 pp.

Naselli-Flores, L. (2008). Urban lakes, ecosystems at risk, worthy of the best care. In: Materials of the $12^{\text {th }}$ World Lake Conference, Taal, 2007. Jaipur, pp. 1333-1337.

Paxinos, R. G., Mitchell, J. (2000). A rapid Utermöhl method for estimating algal numbers. J. Planc. Res., 12, 2255-2262
Pfister, G., Auer, B., Arndt, H. (2002). Pelagic ciliates (Protozoa, Ciliophora) of different brackish and freshwater lakes a community analysis at the species level. Limnologica, 32, 147-168.

Shannon, C. E., Weaver, W. (1949). The Mathematical Theory of Communication. University of Illinois Press, Urban. 125 pp.

Stoecker, D. K., Davis, L. H., Anderson, D. M. (1984). Fine scale spital petween plantonic ciliates and dinoflagellates. J. Planc. Res., 6 (5), Contribution No. 5532.

Van Wichelen, J., Johansson, L. S, Vanormelingen, P., Declerck, S. A., Lauridsen, T. L., De Meester, L., Jeppesen, E., Vyverman, W. (2013). Planktonic ciliate community structure in shallow lakes of lowland Western Europe. Eur. J. Protistol., 49, 538-551.

Velho, F. M., Pereira, D. G., Pagioro, T. A., Santos, V. D., Perenha, M. C. Z., Lansac-Töha, F. A. (2005). Abundance, biomass and size structure of planktonic ciliates in reservoirs with distinct trophic states. Acta Limnol. Brasil., 17 (4), 361-371.

Weisse, T., Stadler, P. (2006). Effect of pH on growth, cell volume, and production of freshwater ciliates, and implications for their distribution. Limnol. Oceanogr., 51 (4), 1708-1715.

Wu, J. (2014). Urban ecology and sustainability: The state-of-the-science and future directions. Landsc. Urban Plan., 125, 209-221.

Xu, R., Cronberg, G. (2010). Planktonic ciliates in Western Basin of Lake Ringsjön, Sweden, community structure, seasonal dynamics and long-term changes. Protistology, 6 (3), 173-187.

Yang, J., Löder, M. G. J., Gerdts, G., Wiltshire, K. H. (2014). Structural composition and temporal variation of the ciliate community in relation to environmental factors at Helgoland Roads, North Sea. J. Sea Res., SEARES-01274.

Yoshioka, A., Miyazaki, Y., Sekizakic, Y., Suda, S., Kadoya, T., Washitani, I. (2014). A "lost biodiversity" approach to revealing major anthropogenic threats to regional freshwater ecosystems. Ecol. Ind., 36, 348-355.

Zingel, P. (2001). The Role of Planctonic Ciliates in Lake Ecosystems. Tartu University Press, Tartu. $111 \mathrm{pp}$.

Zou, Q., Lu, Z., Li, Ch., Li, Y., Huang, P. (2013). Seasonal pattern of planktonic ciliates in a subtropical shallow urban lake. Curr. Res. J. Biol. Sci., 5 (5), 210-219.

Received 15 June 2015

\section{PROTOZOOPLANKTONA SABIEDRĪBAS VIDES FAKTORU IETEKMĒ RĪGAS PILSĒTAS SEKLAJOS EZEROS UN KARJEROS}

Ciliāti kā vadošā protozooplanktona grupa ir būtiski mikrobiālās ḳēes komponenti. Pateicoties savai bioloğiskajai organizācijai, ciliāti ir labi zināmi arī kā bioindikatori, jo spēj strauji reaǵêt uz apkārtējās vides izmaiṇām. Urbānās vides hidroekosistēmas ir relatīvi maz pētītas, tāpēc darba gaitā uzsākti pētījumi četrās Rīgas pilsētas un piepilsētas ūdenstilpēs ar mērḳi iegūt informāciju par ciliātu sezonālo sukcesiju, analizējot to bioloǵisko daudzveidību, skaitu, biomasu, populāciju izmēra struktūru dinamiku saistībā ar vides abiotiskiem un biotiskiem faktoriem. Rezultāti liecina, ka Gaiḷezeru un Bābelīša ezeru var izmantot kā modeḷsistēmu urbānā stresa novērtējumam, savukārt Bolderājas 